小特集 ディジタルサイネージ

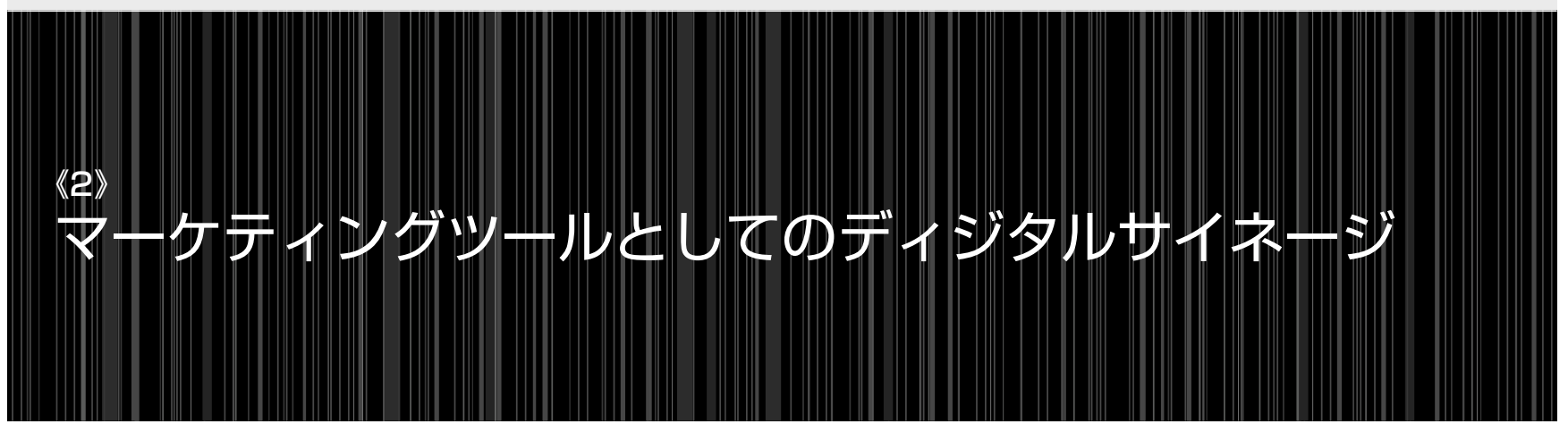

町田 聡†

キーワード ディジタルサイネージ，クロスメディアマーケティング， AR

1 ま え が き

「ディジタルサイネージ」は，ハードウェアやソフトウェ アなどのシステム的な要素に加えて, ロケーションやコン テンツといった極めて定量化しにくい要素があり, さらに は, 広告主や広告代理店, 運用者, 生活者 (利用者)など, 多くのプレーヤが複雑に関係してくるという特徵を持って いる.

したがって，一口に「ディジタルサイネージ」とくくって しまうと, インテグレータと発注者の間で, その果たすべ き役割や機能について共通の認識が持てない恐れがあると 同時に, プレーヤの立場によってはまったく異なる要件が 求められる可能性も出てくる.

本稿では，まずディジタルサイネージ自体の目的を整理 し, その使われ方をマーケティングの観点から解説するこ とで, 特定の問題解決に役立つディジタルサイネージを構 築するために必要な考え方を紹介する.

2 ディジタルサイネージの基礎

\section{1 ディジタルサイネージの定義}

ディジタルサイネージを一言で定義すると，「時間と場 所を特定できる唯一のメディア」となる.

「通信を使用して・・」や「屋外において・・」，「電子的 に・・」云々と定義されることがあるが, どれも本質を得 ているとは言えず，この「時間と場所を特定できる唯一の メディア」というのが，ディジタルサイネージを本質的に 理解する上で最も適した定義であると筆者は考える.

これに対してテレビやラジオは，「時間を特定できるメ ディア」であり, 屋外広告は「場所を特定できるメディア」, Webは，一般的に「時間も場所も特定できないメディア」 といえる.

さらに，ディジタルサイネージの本質を理解するには， 時間を含んだ場所 (=ロケーション) 自体がメディアである

* 本稿の著作権は, 著者に帰属致します.

†コンテンツサービスプロデューサ

"Digital Signage As Marketing Tool" by Satoshi Machida (Digital Content-service Producer, Tokyo)
ことを忘れてはならない。設置するディスプレイやSTB (Set Top Box) がメディアではなくて，その場所自体が特 性をもったメディアなのであり，そのメディアの価值を利 用することでディジタルサイネージが成立しているという ことである.

\section{2 ディジタルサイネージの分類}

「ディジタルサイネージ」という言葉は総称である．前項 に従うと，「時間と場所を特定できる唯一のメディア」全体 をさしているわけで, 実際にどのような機能を果たせるの かこれだけでは理解することができない.

本項では，より具体的にディジタルサイネージを理解す るために，ディジタルサイネージの果たす役割を表1のよ うに分類する.

これらの目的は単独で利用されることもあるが，組合せ て効果を発揮させることもできる．例えば，画面の半分に 時計を表示し情報提供を行いながら，あとの半分に広告を 入れるという古典的な手法もその例である.

一方, 空港の発着案内のように, 必ずしも「ディジタル サイネージ=広告」ではなく, 情報提供やアンビエントな どの広告を伴わない利用目的も存在することを忘れてはな らない.

\section{3 ディジタルサイネージのワークフロー}

ディジタルサイネージの全体像を把握するためには, そ のワークフローを理解することが有効である．例えば図1

表1 ディジタルサイネージの目的分類

\begin{tabular}{|c|c|c|}
\hline 目 的 & 解 説 & 使用例 \\
\hline 1. 情報提供 & $\begin{array}{l}\text { その場に必要な情報を提供 } \\
\text { すること }\end{array}$ & "空港の発着案内など \\
\hline $\begin{array}{l}\text { 2. ブランディン } \\
\text { グ・広告 }\end{array}$ & 商品や企業を宣伝すること & $\begin{array}{l}\text { 企業のマークが出る, その } \\
\text { 場では買えなくとも知らし } \\
\text { めるなど }\end{array}$ \\
\hline 3. 販売促進 & $\begin{array}{l}\text { その場で買えるものを宣伝 } \\
\text { すること }\end{array}$ & $\begin{array}{l}\text { スーパーの商品棚で, その } \\
\text { 商品を宣伝するなど }\end{array}$ \\
\hline 4. 集 客 & 特定の場所に人を集めること & $\begin{array}{l}\text { 音や匂い, 娛楽などで人を } \\
\text { 集めるなど }\end{array}$ \\
\hline 5. 送客・誘導 & $\begin{array}{l}\text { 特定の場所に人を誘導する } \\
\text { こと }\end{array}$ & $\begin{array}{l}\text { クーポン券を配り, 店舗に } \\
\text { 足を運ばせるなど }\end{array}$ \\
\hline 6. アンビエント & $\begin{array}{l}\text { 映像情報を環境の一部とし } \\
\text { て取り达むこと }\end{array}$ & $\begin{array}{l}\text { ビルのアトリウムで気温変 } \\
\text { 化を映像化するなど }\end{array}$ \\
\hline
\end{tabular}




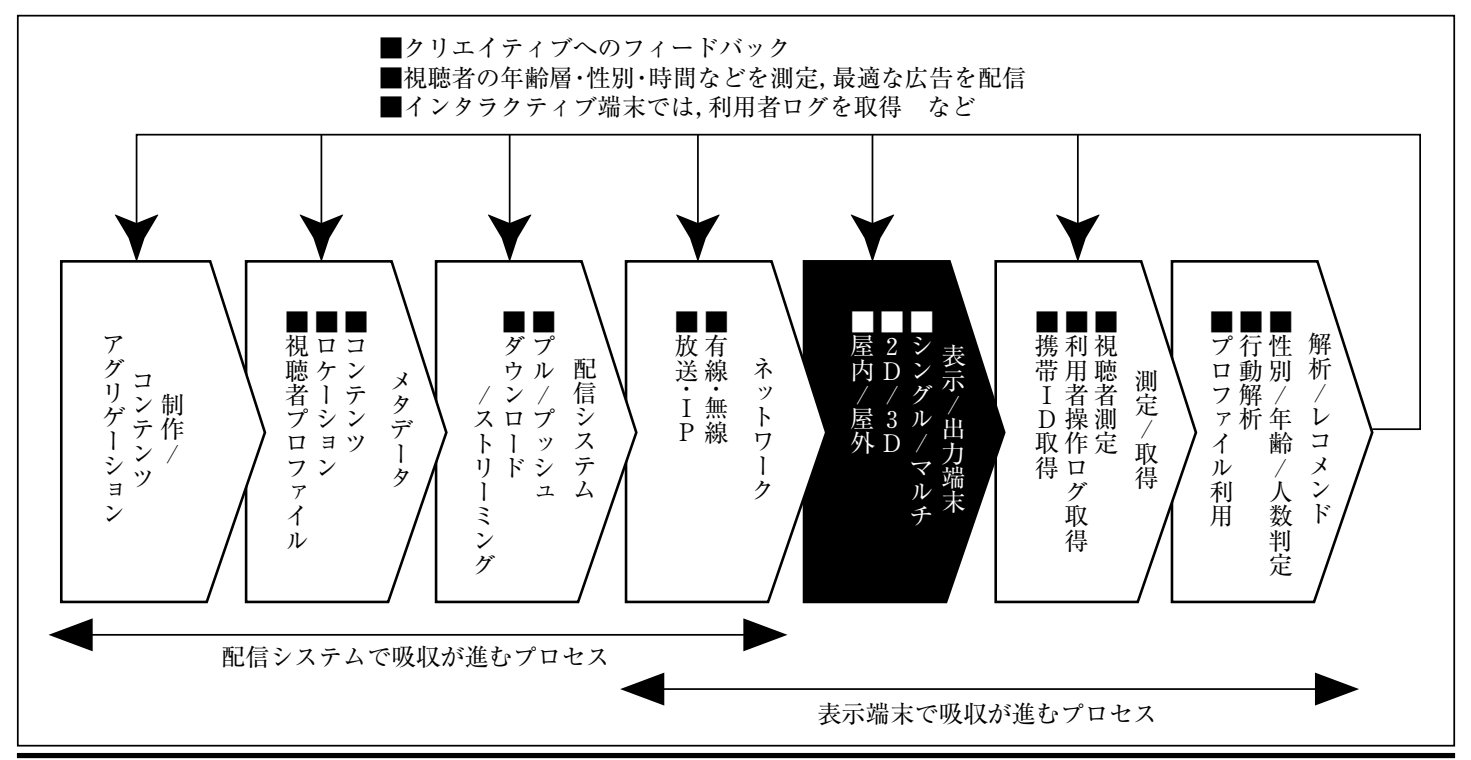

図 1 ディジタルサイネージのワークフロー

にある表示部であるが，ここから川下 (測定，解析)，川上 (配信, 制作) へと理解を進めていくとわかりやすい. 図1 はディジタルサイネージに必要と思われるすべての機能を 盛り込んだものであるが，もちろんすべてを網羅する必要 はなく, 単にビデオを再生する表示部だけのものであって も良いのである，そのシステムの人手によるビデオ交換を ネットワーク経由に変更することで，コストが下がるので あれば随時図1にあるような川上と川下の機能を検討して 加えていけばよいのである.

また，図1の下部にある矢印が示す通り，機器側でも機 能の集約が進んでおり, 従来であればディスプレイとプレ 一ヤ，PCなど複数の機器が必要であったが，昨今はそれら がディスプレイに一体化されてきている.

3 クロスメディアマーケティング

分野が違う方にとっては, 耳慣れない言葉かもしれないが, マーケティングの世界では最近「クロスメディア」という言 葉をよく耳にする，特にWebや携带電話の普及につれてそ の頻度は高まってきているといえる，要はテレビ，新聞， ダイレクトメール，電車の中づりというふうにたくさんの メディアがあり，それを組合せることで，相乗効果を最大 限に発揮しょうというのが, クロスメディアの考え方であ る.これに対して，以前からあるメディアミックスという 考え方は, 情報伝達の経路を増やすという足し算的な発想 であるといわれている。つまり, クロスメディアとは掛け 算的にメディアを活用する手法というわけである(図2).

デイジタルサイネージもこのクロスメディアのなかで考 えられるべきである. 図1で説明したディジタルサイネージ のワークフローと, 図2のクロスメディアのワークフローは, メディアの連携や相乗効果を上げるという点では大変密接 な関係にある，具体的には，ディジタルサイネージで表示

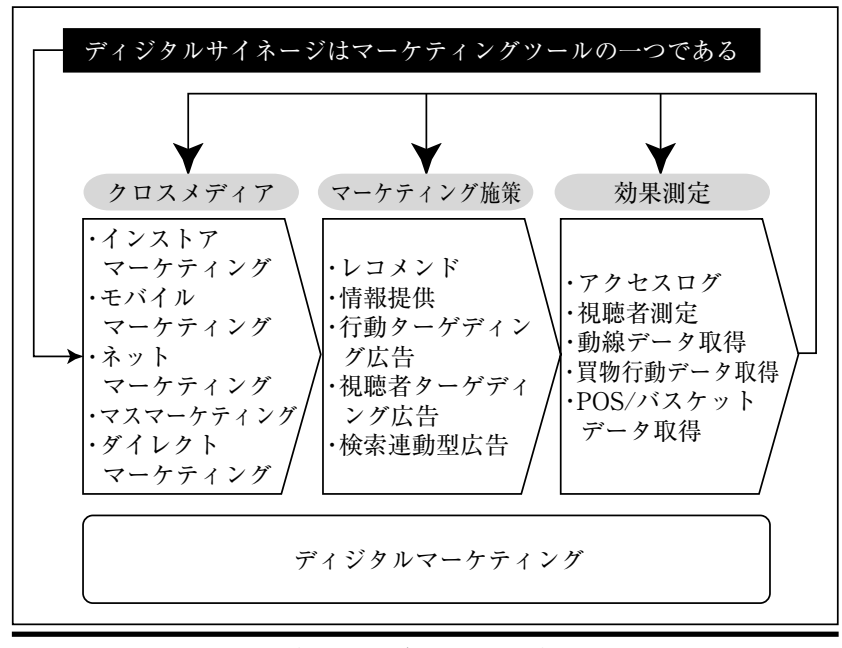

図2 クロスメディアのワークフロー

されている店舗のクーポンをディジタルサイネージ端末に あるフェリカ機能で携带電話に取り込み, 店舗に出向いて クーポンを提示し，割引を受けることなどが想定される.

つまり, デイジタルサイネージだけではなく, 携帯電話 を連携させることで初めて, 送客が可能となるわけで，こ の相乗効果がクロスメディアなのである.

デイジタルサイネージを他のメディアと連携させる場合 は，どのメディアとどのように連携し，目的を達成させる のか，その要件をあらかじめ設計しておく必要がある.

それは, クロスメディアマーケティング全体の効果とし てマーケティング施策の中で設計されるべきで，この設計 の成否がデイジタルサイネージ自体の成否にもかかわるこ とになる。

\section{4 クロスメディアでの活用事例}

では，実際にクロスメディアを活用したディジタルサイ 
ネージとはどのようなものかその事例をみてみよう.

\section{1 印刷物との連携}

クロスメディアというと, 高度なシステムが要求される と思われるかもしれないが，いたってシンプルなケースが 多い，それは，デイジタルサイネージ自体にコストをかけ られないという事情があるからであり, またデイジタルサ イネージの効果測定が確立されていないという背景による ところが大きいと思われる.

その中でも, 印刷メディアとディジタルサイネージの連 携は, 古典的なメディアとして確立されている印刷メディ アとITを融合することで相乗効果が得られるわかりやすい 例である。

\subsection{1 印刷物配布促進での活用例}

駅などの交通機関で見かけるカタログやパンフレットの 配布棚.これとディジタルサイネージを組合せることも大 変効果がある.この場合の目的は明確にカタログの配布に あるべきであり, その場合であれば, ディジタルサイネー ジを採用した場合と, 採用しなかった場合でのカタログ配 布数を比較すれば，その効果は明確になるはすである.

日本でもこの試みはいくつか実施されているが，筆者が みる限りではそれは成功しているとは思えない，その理由 は明確である。ディジタルサイネージを見せたいのか，カ タログを配布したいのか，はたまた，携帯でタッチしてほ しいのか, その目的が明確でないからである(あるいは多 くのことを歩行者に求めすぎているからである).

それはディスプレイとカタログ棚の大きさのバランス や, 流すコンテンッやメッセージの内容, 置いてある場所 など，すべてを考慮して初めて「カタログ配布を促進する」 という目的が達成されるのであるが，それに対する配慮が 不足しているからと思われる (図3).

これに対して, 図4は，オランダのスキポール空港にあ る免税品用のパンフレット配布棚であるが，これは極めて 優れた印刷物とデイジタルサイネージの融合例である.

だれが見てもパンフレットの配布が目的だとわかる。そ の理由はパンフレットとディスプレイの大きさのバランス であり，パンフレットの取り易さからもわかる.

一方, ディジタルサイネージの役割はパンフレットを手 に取らなくとも，これは何のパンフレットで，パンフレッ トにはなにが出ているのか, その概要を伝えることに専念 しており，ちょうどディスプレイの文字が読みやすい距離 がパンフレットへ手を伸ばそうかと思える距離なのである.

要はお互いが一つの目的にそってその役割を果たしている わけであり，これがクロスメディア利用の極意だと考える.

今後ディジタルサイネージのシステムを設計する機会に は, 是非このローテク事例を思い出していただけると, 何 が重要か参考になるはずだ

\subsubsection{DARによる活用例}

ARはAugmented Reality = 拡張現実の略であり, 本来は

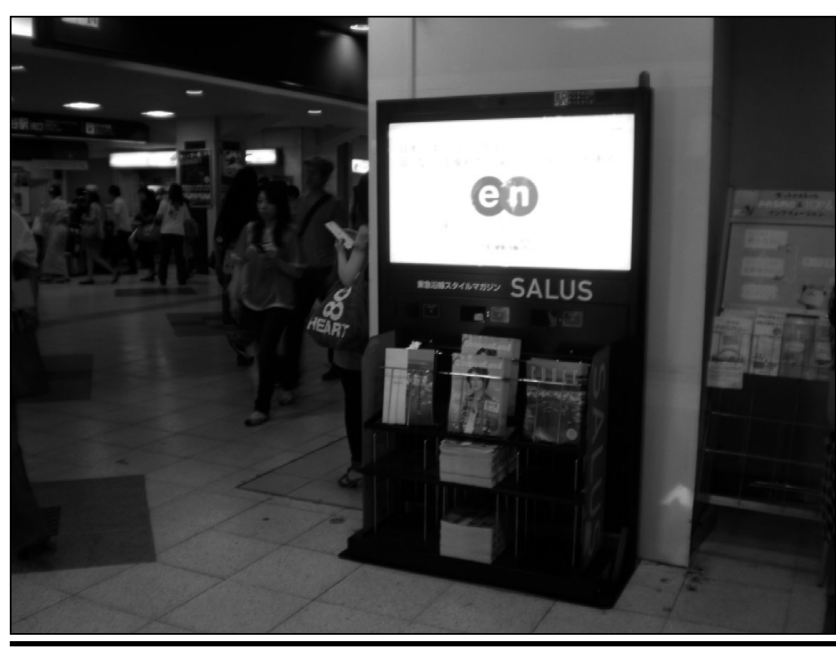

図3印刷物配布促進での活用例（口絵力ラー参照）

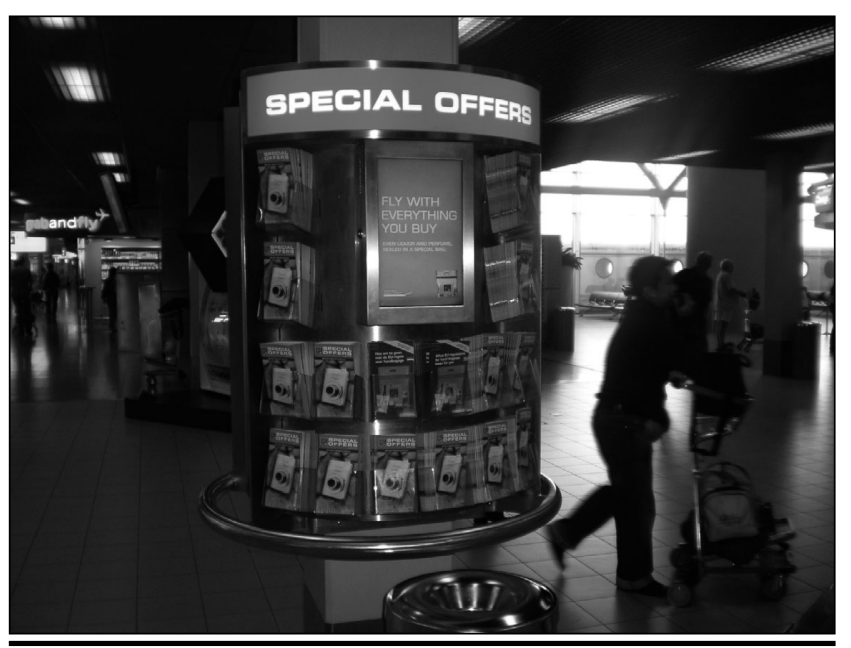

図4 オランダのスキポール空港にある免税品用のパンフレット配布棚 (口絵力ラ一参照)

IT系の研究者の方々が専門にされている分野であろう.

しかし，ARという言葉が普及している背景には，その 利用のされ方として，マーケディングで多く使われている という事実がある. 少なくとも, マーケティングやディジ タルサイネージ業界では, ARという言葉が一般的になっ てきている.

本節では，AR技術のなかでも印刷物との相乗効果が最大 限に発揮できるイメージマーカ方式での事例を取り上げる.

ARのトラッキング方式には, そのほかにもマーカや顔 認識を利用したものもあるので，それらの特長を表2にま とめておく.

表2でもわかるとおり，印刷との連携を考えると，マー カトラッキング方式か, イメージマーカトラッキング方式 (マーカレス方式とも言われることがある) が適していると いえる.

さらに, マーカトラッキング方式とイメージマーカトラッ キング方式を比べると, 実は大変大きな違いが見えてくる. 
表2 APトラッキング方式の特長

\begin{tabular}{|c|c|c|}
\hline トラッキング方式 & 特 長 & $\begin{array}{l}\text { ディジタルサイネージで } \\
\text { の主な用途 }\end{array}$ \\
\hline マーカトラッキング & $\begin{array}{l}\text { 事前に印刷物やデータな } \\
\text { どで配布したマーカを持 } \\
\text { 参しないと体験できない }\end{array}$ & $\begin{array}{l}\text { 特殊マーカを持参した人 } \\
\text { が体験可能. 集客に利用 }\end{array}$ \\
\hline フェイストラッキング & $\begin{array}{l}\text { なにも持参しなくとも，} \\
\text { 通りがかりに顔が映れば } \\
\text { 体験可能 }\end{array}$ & $\begin{array}{l}\text { ディスプレイ周辺の集客 } \\
\text { やアテンションに利用 }\end{array}$ \\
\hline $\begin{array}{l}\text { イメージマーカトラ } \\
\text { ッキング }\end{array}$ & $\begin{array}{l}\text { 製品の箱を持参するな } \\
\text { ど，製品の購買行動と直 } \\
\text { 結した利用が可能 }\end{array}$ & $\begin{array}{l}\text { 特定の製品やカタログを } \\
\text { 持参した人が体験可能. } \\
\text { 集客や販売促進に利用 }\end{array}$ \\
\hline
\end{tabular}

それは，印刷物の準備が事前に必要か，それとも既存の 印刷物を利用できるかという点であり，マーカトラッキン グ方式は, 特殊なマーカが印刷された印刷物が必ず必要と なり，それ以外の印刷物では利用することができないのに 対して, イメージマーカトラッキング方式は, 既存の印刷 物, 例えばカタログや杂隹誌の表紙, バースデーカード, ス ーパーのチラシ, チョコレートの箱, 企業のロゴマークな ど，あらゆるものをトラッキングの対象にすることができ る柔軟性がある。

それらのイメージを登録しておくことで, トラッキング の対象を変更することができるのである(イメージマーカ トラッキング方式は, マーカトラッキング方式にも, もち ろん対応可能である).

この点を活用することで, カタログや新聞折り込み広告と の連携などが可能となる.下記に, サイバネットシステム がドイツMETAIO社のARツールで構築した事例を示す.

・クライアント：ブックローン(株)

・導入目的：ブロック玩具「リブロック」の販売促進

- 導入時期 : 2010 年 3 月

- 導入場所：イオンモール大和郡山喜久屋書店ほか 4 店舗

・内 容：箱をディスプレイ前にかざすと組み立て完 成品が3Dで合成表示され，子供の購買意欲 を誘う。欧州LEGO社が3000台の専用端末 を導入して，実施したMETAIO社の例を参 考に日本で展開したもの.

\section{5 むすび}

「ディジタルサイネージ」という漠然とした内容をマーケテ イングの立場からひも解いてみることは, アプリケーション からシステムを考える上で大変重要なことである．往々にし て，ディジタルサイネージ自体がアプリケーションと思われ がちであるが，それ自体が総称であり，実態がないわけだか らそれをターゲットにするとシステムは成功しない.つまり, ディジタルサイネージを導入することが目的となり，そこか らは成果が得られないということになる.

マーケティング以外の利用においても同様である, 情報 伝達での利用や建築の一部として使われる場合において も, それぞれの目的を明確にし, その目的達成に向かった システム構築が必要となってくる.

できれば，今後はディジタルサイネージという観点では なく,「販売支援システム」や「電子ポス夕」,「クーポン発 券機」など，具体的な用途に合わせた名称を付けた方がわ かりやすいかも知れない.

またこのような表示が中心のメディアは，従来一方的に 情報を発信するのが常であったが，今後は情報の受け手が 欲する情報を生活環境のなかで適切に提示できる，「人に やさしい情報環境」として成熟させていくことが望まれる. 筆者はそれをアンビエントサイネージと呼んでおり, 生活 者の視点から, そのような情報環境の提供を目指したいと 思っている. それは, ユビキタス社会の次に訪れるアンビ エント社会の重要な要素となってくるはずである.

(2010年9月6日受付)

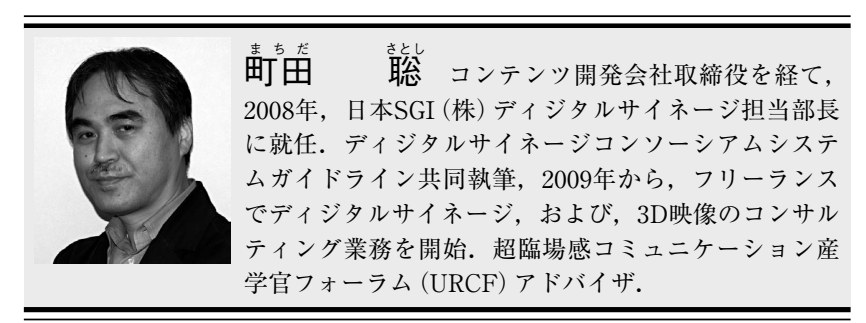

